INDONESIA ACCOUNTING JOURNAL

VOLUME 3, NUMBER 1, YEAR 2021

${ }^{1}$ Corresponding author

Accounting Programme

Economics and Business Faculty

Stikubank University

Jl. Kendeng 5, Bendan Duwur, Gajahmungkur

Semarang City, Central Java Province, Indonesia, 50233

E-mail: eristamia.fm@gmail.com

${ }^{2}$ Accounting Programme

Economics and Business Faculty

Stikubank University

Jl. Kendeng 5, Bendan Duwur, Gajahmungkur

Semarang City, Central Java Province,

Indonesia, 50233

Article info:

Received 31 March 2021

Accepted 1 April 2021

Available online 1April 2021

Keywords: audit delay; auditor's opinion; reputation of public accounting firm; ROA

JEL Classification: $\mathrm{H}_{83}, \mathrm{M}_{41}, \mathrm{M}_{42}$

DOI: http://doi.org/10.32400/iaj.33169

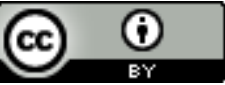

This work is licensed under a Creative

Commons Attribution 4.0

International License.

\section{Analysis of factors affecting audit delay in manufacturing and financial companies listed on IDX}

\author{
Eristamia Faizul Muna ${ }^{1}$ \\ G. Anggana Lisiantara ${ }^{2}$
}

\begin{abstract}
The study aims to identify and analyze the factors affecting the audit delay. The study includes a quantitative study using secondary data obtained from the company's financial statement. The study's population constituted the entire manufacturing and finance companies listed on the Indonesia Stock Exchange during the year 2018-2019. The sample is collected by using purposive sampling over the listed companies in the criteria that the company publishes the audited financial report as of December 31 and also shows the data needed in the study. The sample which has met the criteria is 510 companies and analyzed by multiple linear regression analysis. The results show that the industrial type and complexity of the company have a positive influence on the audit delay, the auditor opinions, the reputation of Public Accounting Firm and the company's size have a negative impact on the audit delay, while the profitability does not affect the audit delay.
\end{abstract}

\section{Introduction}

Financial reports contain information from the accounting process that can be used by management to evaluate the performance of the company and can be used as a basis for consideration of decision making in future periods. The most important thing in the submission of financial reports is the timeliness. According to Debbianita et al. (2018), information in financial statements that is presented in a timely manner will have more benefits so that it can help users make decisions. On May 9, 2019, there were 24 issuers who had not submitted audited financial reports as of December 2018, so the Indonesian Stock Exchange (IDX) has sanctioned the delay in submitting and publishing these financial reports (Ayuningtyas, 2019). Kuncaratrah (2019), and Felicia and Pesudo (2019) find that the common cause of delays in the publication of a company's financial statements tends to be due to the delay in carrying out the audit (audit delay) on these financial statements.

Some empirical evidence shows that there are several factors that can affect audit delay. Hakim and Sagiyanti (2018) find that the type of industry has a significant effect on audit delay, although previously Primantara and Rasmini (2015) prove that the type of industry has no effect on audit delay. In addition to the type of industry, Amani and Waluyo (2016) find that auditor opinion also affects audit delay when Miradhi and Juliarsa (2016) prove that this 
factor is not significant for audit delay. Other empirical evidence also shows that the reputation of the Public Accounting Firm (or $K A P$ ) has a significant effect on audit delay (Saputri, 2012). Furthermore, Darmawan and Widhiyani (2017) show that the complexity of company operations can also lead to extended audit delays even though these results are inconsistent with Rachman and Ardini (2016). This study discusses the impact of the audit completion time on the financial statements on the timeliness of the publication of audited financial report information outside the specific factors of the company itself where the length of the audit delay is called the audit delay. The purpose of this study is to provide empirical evidence on the factors that affect audit delay, which consists of the type of industry, auditor opinion, KAP reputation and the complexity of company operations.

\section{Literature review Basic concepts}

Agency theory. According to Scott (2000), agency theory is a branch of game theory that studies the scheme of contracts to motivate rational agents to act according to the wishes of the principal. Agency relationships arise when one or more individuals (principals) examine other individuals (agents or employees) to act on their behalf, delegating the power to make decisions to agents and employees (Firmansyah et al., 2016). The main factor that must be considered before implementing agency theory is audit delay. Audit delay has a definition as the time span of the audit task completion process by the auditor on financial statements (Halim, 2000). Punctuality itself has a close relationship with audit delay in the publication of financial reports, if not submitted in a timely manner, it can reduce the benefits of financial reports (Lisa, 2015). Punctuality shows the time interval between information is not delivered on time resulting in the value of the information being reduced (Praptika and Rasmini, 2016).
Audit delay. Audit delay is the length of time for audit completion which is measured from the date of book closing until the audited report is completed by the auditor (Utami, 2006). Based on POJK Number 20/POJK.04/2016, public companies listed on the IDX are required to submit an annual financial report accompanied by an independent auditor's report to the Financial Services Authority (or $O J K$ ) and announce it to the public no later than the end of the fourth month or 120 days after closing book ends. The regulation also states the sanctions if the company experiences an audit delay, namely written warnings, fines, restrictions and freezing of business activities, revocation of business licenses, cancellation of approval and cancellation of registration.

\section{Hypothesis development}

Industry type and audit delay. Different industry characteristics can cause differences in the time span in the audit process and in the publication of financial reporting to the public (Purnami et al., 2019; Susianto, 2017). Financial companies tend to have shorter audit delays than companies from other types of industries because financial companies do not have complex accounting recording specifications (such as inventory) so that the audit process does not require a long time (Ashton et al., 1987; Kurniawan and Laksito, 2015; Hakim and Sagiyanti, 2018). Empirical evidence from Ashton et al. (1987), Kurniawan and Laksito (2015), Haifa (2017), Susianto (2017), Hakim and Sagiyanti (2018), and Purnami et al. (2019) show that the type of industry, especially the non-financial industry, has a longer audit delay. In contrast, Sunaningsih and Rohman (2014), and Primantara and Rasmini (2015) find that industry type did not significantly affect audit delay. Based on existing empirical evidences, the following hypothesis can be formulated for this study. H1: The type of industry has a positive effect on audit delay

Auditor opinion and audit delay. The auditor's opinion is an opinion expressed by 
an independent auditor on the fairness of the content of the audited financial statements, in all material aspects and based on the conformity of the composition of the financial statements with generally accepted accounting principles (Mulyadi, 2014:19). The auditor's opinion can be used as a benchmark and a basis for making decisions. Sunaningsih and Rohman (2014), David and Butar Butar (2020), and Rustiarini and Sugiarti (2013) prove that auditor opinion has a negative effect on the delivery of financial statements. Rustiarini and Sugiarti (2013) argue that giving unqualified opinion (or WTP) can minimize audit delay. According to Shulthoni (2013), companies that get other than unqualified opinion will experience a relatively long audit delay. In contrast, Prameswari and Yustrianthe (2017), and Sari and Priyadi (2016) find that auditor opinion does not affect audit delay. Based on existing empirical evidences, the following hypothesis can be formulated for this study.

H2: Auditor's opinion has a negative effect on audit delay

Reputation of KAP and audit delay. The quality of the audits will affect the credibility of the financial statements when the company goes public. The reputation of the $K A P$ hired by a company to audit its financial statements will affect public confidence regarding the credibility of the financial statements produced by the company. Large public accounting firms have a larger number of employees, thus enabling the audit completion process to be on time and have a strong incentive to complete the audit process in order to maintain its reputation. Verawati and Wirakusuma (2016), Kurniawan and Laksito (2015), Sari and Priyadi (2016), and Prameswari and Yustrianthe (2017) prove that the reputation of $K A P$ can affect audit delay because Big Four of $K A P$ is faster in completing its audit. In contrast, Sunaningsih and Rohman (2014) found that the reputation of $K A P$ does not affect audit delay. Based on existing empirical evidences, the following hypothesis can be formulated for this study.

H3: KAP's reputation has a negative effect on audit delay

Complexity of company operations and audit delay. The complexity of an organization or operation is a direct result of the division of labor and the department which focuses on the number of units that differ significantly. Organizations with the number or many types of work and auditing create managerial and organizational problems that are more complex because of the increasingly complex dependencies. The level of complexity of a company's operations, which depends on the number and location of its operating units and verified product lines and markets, is more likely to affect the time it takes for auditors to complete their audit work (Ariyani and Budiartha, 2014). Sulistiyanto and Yuniarto (2012) state that the complexity of the company's operations can be measured by looking at the number of subsidiary entities it owns. Pratiwi and Wiratmaja (2018), David and Butar Butar (2020), Darmawan and Widhiyani (2017), and Widyastuti and Astika (2017) prove that companies that have more subsidiaries can extend the audit delay period. In contrast, Yohaniar and Asyik (2017), and Putra and Wiratmaja (2019) find that the complexity of firm operations does not affect audit delay. Based on existing empirical evidences, the following hypothesis can be formulated for this study.

H4: The complexity of the company's operations has a positive effect on audit delay

\section{Research method}

The type of data used in this study is secondary data. The data is obtained by taking the company's financial statements that have been audited by an independent auditor and published. Financial reports are obtained by accessing the official IDX website (www.idx.co.id). The population in this study are all manufacturing and financial sector companies listed on the IDX in the period of 2018-2019 which give total 527 companies. This study uses purposive 
sampling technique and obtained 460 observational data or 230 companies for each of 2018 and 2019 according to the sample criteria. The sample criteria are as follows: (1) manufacturing and financial companies listed on the IDX in 2018-2019; (2) manufacturing and financial companies that submit financial reports for the period 2018-2019; (3) manufacturing and financial companies that publish financial reports with the closing date of December 31st; (4) manufacturing and financial companies that have annual financial reports that have been audited by a public accounting firm and include reports from independent auditors; and (5) manufacturing and financial companies that have complete data for research. This study uses multiple regression analysis at a significance level of $5 \%$ with the help of the SPSS version 25 and MS Excel application which aims to determine the influence of the independent variable and control variable on the dependent variable. This study uses a dependent variable, namely audit delay and six independent variables, as follows.

- Audit Delay (AUD), which is the length of time for completion of the audit by the auditor, calculated from the closing date of the book as of December 31 to the date stated in the independent auditor's report. The measurement of AUD is carried out quantitatively in the number of days (Rustiarini and Sugiarti, 2013) and is calculated as the difference between the date of the audit report and the date of the financial statements or the date of the audit report minus the date of the financial statements.

- Type of Industry (TYPE), namely the type of industry divided into two groups, namely the financial industry and the manufacturing industry (Primantara and Rasmini, 2015). This variable is measured by a dummy number where financial companies are given a value of 0 and manufacturing companies are given a value of 1.

- Auditor Opinion (OPIN), namely the opinion given by the auditor on the fairness of the presentation of the financial statements of the company where the auditor conducts the audit (Mulyadi, 2014: 19). This variable is measured by a dummy number where the unqualified opinion is given a value of 1 and other opinions are given a value of 0 .

- Reputation of KAP (RKAP), namely the good name it has, the achievements and public trust in the public accounting firm (Rudyawan and Badera, 2009). This variable is measured by a dummy number where Big Four KAPs are given a value of 1 and non Big Four KAPs are given a value of 0 .

- Company Operational Complexity (KOMP), namely the level of complexity of company operations by looking at the number and location of its operating units (Widyastuti and Astika, 2017). This variable is measured by the number of subsidiaries.

- Company Size (SIZE) is one of the control variables in this study which is defined as a grouping of the size of the company which can describe the activities and revenues of the company (Nugraha and Meiranto, 2015). This variable is measured using the natural logarithm of total assets.

- Profitability (ROA) is another control variable of this study and is a financial indicator that describes the company's ability to generate return on total assets owned (Kurniasih and Sari, 2013). This variable is obtained from net profit after tax divided by total assets.

\section{Results and discussions}

\section{Results}

Descriptive statistics. AUD has a minimum value of 16 , a maximum value of 141 , a mean of 78.69 , and a standard deviation of 21.043. TYPE has a minimum value of 0 , a maximum value of 1 , a mean of 0.65 , and a standard deviation of 0.476 . OPIN has a minimum value of 0 , a maximum value of 1 , a mean of 0.79 , and a standard deviation of 0.410 . The RKAP has a minimum value of 0 , a maximum value of 1 , a mean of 0.42 , and a standard deviation of 0.49. KOMP has a minimum value of 0 , a maximum value 
of 57, a mean of 4.06, and a standard deviation of 7.77. SIZE has a minimum value of 14.34 , a maximum value of 30.22 , a mean of 22.03 , and a standard deviation of 2.04. ROA has a minimum value of -1.37 , a maximum value of 9.34 , a mean of 0.05 , and a standard deviation of 0.45 .

Classic assumption test. The normality test aims to test the data to detect the regression model, the confounding variable has a normal distribution or not, with Skewness and Kurtosis statistics. Table 1 shows that $Z_{\text {skewness }}$ is 0,727 or $0,083 /(\sqrt{6 / 460})$ and $Z_{\text {kurtosis }}$ is $-1,265$ or $-0,298 /(\sqrt{24 / 460})$. The $Z_{\text {skewness }}$ and $Z_{\text {kurtosis }}$ are both under 1.96 so this means that the regression model fulfills the normality assumption and it can be concluded that the residual value is normally distributed. According to Ghozali (2019:107), the regression model is declared free of multicollinearity if the relationship between independent variables has a tolerance value above 0.01 and a Variance
Inflation Factor (VIF) value is less than 10. The test results show that TYPE has a tolerance value of 0.715 and a VIF of 1.399 , OPIN has a tolerance value of 0.970 and VIF of 1.031, RKAP has a tolerance value of 0.838 and VIF of 1.193, KOMP has a tolerance value of 0.776 and VIF of 1.288 , SIZE has a tolerance value of 0.637 and VIF of 1.571, and ROA has a value tolerance of 0.985 and VIF of 1.015. All independent variables have a tolerance value of more than 0.01 and a VIF of less than 10, so it can be concluded that there is no multicollinearity. This study also found that the results of the autocorrelation test using the Durbin-Watson test obtained a value of 1.870. This value is then compared with the value in the DW table with a significance of $5 \%$, the number of $\mathrm{N}$ is 460 and the number of $\mathrm{k}$ is 6 variables, so the $\mathrm{dU}$ value is 1.868 . These results indicate that the value of $\mathrm{dU}$ $<\mathrm{dw}<4-\mathrm{dU}$ or $1.868<1,870<2.132$ which indicates that there is no autocorrelation.

Table 1. Result of normality test

\begin{tabular}{lcccccc}
\hline & \multirow{2}{*}{ S } & \multirow{2}{*}{ Std. Deviation } & \multicolumn{2}{c}{ Skewness } & \multicolumn{2}{c}{ Kurtosis } \\
\cline { 4 - 6 } & & & Statistic & Std. Error & Statistic & Std. Error \\
\hline Unstandardized Residual & 460 & \multirow{2}{*}{18,43212434} & 0,083 & 0,114 & $-0,298$ & 0,227 \\
Valid N (Listwise) & 460 & & & & & \\
\hline
\end{tabular}

Multiple linear regression. Table 2 shows that the $t$ test for TYPE, OPIN, RKAP, KOMP, and SIZE control variables has a significance level less than 0.05 , which means that these variables have a significant effect on AUD. On the other hand, ROA has a significance level of 0.321 or greater than 0.05 , so it is declared insignificant to AUD. Based on multiple regression analysis, the following mathematical equation is obtained.

$$
\begin{gathered}
A U D=174,393+5,852-5,591-3,748+0,511- \\
4,336-1,901+\varepsilon
\end{gathered}
$$

The coefficient of determination is used to test the goodness-fit of the regression model (Ghozali, 2019:179). The results of the regression analysis show that the coefficient of determination with the adjusted $\mathrm{R}$ square $\left(R^{2}\right)$ is 0.246 , which means that $24.6 \%$ of the AUD model can be explained by TYPE, OPIN, RKAP, KOMP, SIZE, and ROA, while $75.4 \%$ is explained by factors others not included in the model. The model feasibility test or the F test aims to show whether all the independent variables included in the model have a simultaneous influence on the dependent variable (Ghozali, 2016:179). The results of the F test have an $\mathrm{F}$ value of 24.593 with a significance value of less than $0.05(0.000$ $<0.05)$ so that these results indicate that the regression model is feasible. 
Table 2. Result of multiple linear regression

\begin{tabular}{|c|c|c|c|c|c|}
\hline \multirow{2}{*}{ Model } & \multicolumn{2}{|c|}{$\begin{array}{c}\text { Unstandardized } \\
\text { Coefficients }\end{array}$} & \multirow{2}{*}{$\begin{array}{c}\begin{array}{c}\text { Standardized } \\
\text { Coefficients }\end{array} \\
\text { Beta }\end{array}$} & \multirow{2}{*}{$\mathbf{t}$} & \multirow[t]{2}{*}{ Sig. } \\
\hline & B & Std. Error & & & \\
\hline Constant & 174,393 & 12,246 & & 14,241 & 0,000 \\
\hline TYPE & 5,852 & 2,133 & 0,132 & 2,743 & 0,006 \\
\hline OPIN & $-5,591$ & 2,127 & $-0,109$ & $-2,629$ & 0,009 \\
\hline RKAP & $-3,748$ & 1,897 & $-0,088$ & $-1,975$ & 0,049 \\
\hline KOMP & 0,511 & 0,125 & 0,189 & 4,075 & 0,049 \\
\hline SIZE & $-4,336$ & 0,526 & $-0,421$ & $-8,236$ & 0,000 \\
\hline ROA & $-1,901$ & 1,915 & $-0,041$ & $-0,993$ & 0,321 \\
\hline \multicolumn{6}{|c|}{ Adjusted $\mathrm{R}^{2}=0,246$} \\
\hline \multicolumn{6}{|c|}{ Std Error of the Estimate $=18,396$} \\
\hline \multicolumn{6}{|c|}{$F=24,593(0,000)$} \\
\hline
\end{tabular}

\section{Discussions}

Industry type and audit delay. The result of hypothesis testing show that TYPE has a positive and significant effect on AUD so that $\mathrm{H} 1$ is accepted. The result of this study is consistent with Ashton et al. (1987), Kurniawan and Laksito (2015), Haifa (2017), Susianto (2017), Hakim and Sagiyanti (2018), and Purnami et al. (2019) but inconsistent with Sunaningsih and Rohman (2014), and Primantara and Rasmini (2015). This study empirically proves that the nonfinancial industry has a longer audit delay than the financial industry because the financial industry tends to have assets in the form of monetary assets that are easier to measure. According to Hati and Sari (2020), non-financial industry assets are generally in the form of physical assets (for example in the case of inventory accounts) so they tend to be more complex and often result in misstatements.

Auditor opinion and audit delay. The result of hypothesis testing indicate that OPIN has a significant negative effect on AUD so that $\mathrm{H} 2$ is accepted. The result of this study is consistent with Sunaningsih and Rohman (2014), Rustiarini and Sugiarti (2013), but inconsistent with Prameswari and Yustrianthe (2017), and Sari and Priyadi (2016). This study empirically proves that companies that get opinions other than unqualified tend to experience a longer delay process because the company views these opinions as bad news resulting in a longer audit process, besides the process of obtaining an unqualified opinion will cause the process to become longer due to negotiations with the auditor at first (Kartika, 2011).

Reputation of KAP and audit delay. The result of hypothesis testing indicate that the RKAP has a significant negative effect on AUD so that H3 is accepted. The result of this study is consistent with Sutjipto et al. (2020), Verawati and Wirakusuma (2016), Kurniawan and Laksito (2015), Sari and Priyadi (2016), and Prameswari and Yustrianthe (2017) but inconsistent with Sunaningsih and Rohman (2014). This study empirically proves that the services of auditors with a good reputation or the Big Four can reduce the possibility of delays in the publication of audited financial reports.

Complexity of company operations and audit delay. The result of hypothesis testing show that KOMP has a significant positive effect on AUD so that H4 is accepted. The result of this study is consistent with David and Butar Butar (2020), Darmawan and Widhiyani (2017), and Widyastuti and Astika (2017) but otherwise inconsistent with Yohaniar and Asyik (2017), and Putra and Wiratmaja (2019). The number of subsidiaries can affect the level of complexity of the company's operations so that it can affect the time it takes for auditors to complete their duties where auditors take a long time to examine the company's financial statements and check transactions carried out in operational units to ensure that the operating unit's financial statements do not make any irregularities. This study supports Rahmawati and 
Suryono (2015) in proving that the complexity of the company's operations extends the time needed for audits.

Company size and audit delay. The test results with the SIZE control show a negative and significant impact on AUD. This result is consistent with the research of Cahyanti et al. (2016), Zebriyanti and Subardjo (2016), and Sari and Priyadi (2016) but inconsistent with Prameswari and Yustrianthe (2017). This study supports Suparsada and Putri (2017) in proving that company size affects the length of audit delay because companies with large total assets tend to immediately submit financial reports, in other words good management causes shorter audit periods with the aim of informing the public. that the company has good prospects during its operation.

Profitability and audit delay. The test result with ROA control show insignificant impact on audit delay. This result is consistent with Septariani (2014), Zebriyanti and Subardjo (2016), and Cahyanti et al. (2016) but inconsistent with Prameswari and Yustrianthe (2017), and Sari and Priyadi (2016). Empirically, this study proves that the audit process for companies that have a low profit level is not different from the audit process for companies that have a higher profit rate where each company will try to speed up the audit process in order to attract the attention of investors and avoid sanctions from capital and government supervision. On the assumption of agency problems, this study proves that audit delay is not caused by a conflict of interest between the principal and the agent, especially in manufacturing and financial sector companies listed on the IDX in the 2018-2019 period.

\section{Conclusion}

This study provides empirical evidence in the context of agency theory or agency problems between principal and agent. Empirically, this study proves that audit delay is not caused by a conflict of interest between the principal and the agent. This reason is reinforced by the evidence that profitability problems or profit problems are not factors that cause the long audit process to occur. It can also be assumed that the value of information for principals or investors does not decrease for the purpose of making investment decisions. The empirical evidence from this study is limited to manufacturing and financial sector companies listed on the IDX in the 20182019 period. This study only conducted observations for 2 years and was limited to only four independent variables and two control variables, so the next researcher should be able to add or use other independent variables that allow greater attachment to audit delay as the dependent variable and make observations with a longer period.

\section{Data availability}

The research data can be accessed openly in the supporting document of the article (supplementary file).

\section{References}

Amani, F. A., \& Waluyo, I. (2016). Pengaruh ukuran perusahaan, profitabilitas, opini audit, dan umur perusahaan terhadap audit delay (Studi empiris pada perusahaan property dan real estate yang terdaftar di Bursa Efek Indonesia pada tahun 2012-2014). Nominal, Barometer Riset Akuntansi dan Manajemen, 5(1), 135-150. https://doi.org/10.21831/nominal.v5i1.11482

Ariyani, N. N. T. D., \& Budiartha, I. K. (2014). Pengaruh profitabilitas, ukuran perusahaan, kompleksitas operasi perusahaan dan reputasi KAP terhadap audit report lag pada perusahaan manufaktur. EJurnal Akuntansi, 8(2), 217-230. https://ocs.unud.ac.id/index.php/Akuntansi/art icle/view/8120

Ashton, R. H., Willingham, J. J., \& Elliott, R. K. (1987). An empirical analysis of audit delay. Journal of Accounting Research, 25(2), 275-292. https://doi.org/10.2307/2491018

Ayuningtyas, D. (2019). Perhatian! 24 emiten ini kena sanksi BEI, kenapa? https://www.cnbcindonesia.com/market/20190 509090006-17-71388/perhatian-24-emiten-inikena-sanksi-bei-kenapa

Cahyanti, D. N., Sudjana, N., \& Azizah, D. F. (2016). Pengaruh ukuran perusahaan, profitabilitas, dan solvabilitas terhadap audit delay (Studi pada perusahaan LQ 45 sub-sektor bank serta property dan real estate yang terdaftar di Bursa Efek Indonesia (BEI) Tahun 2010-2014). Jurnal Administrasi Bisnis, 38(1), 68-73. http://administrasibisnis.studentjournal.ub.ac.id /index.php/jab/article/view/1483

Darmawan, I. P. Y., \& Widhiyani, N. L. S. (2017). 
Pengaruh ukuran perusahaan, kompleksitas operasi perusahaan dan komite audit pada audit delay. E-Jurnal Akuntansi, 21(1), 254-282. https://ocs.unud.ac.id/index.php/Akuntansi/art icle/view/32995

David, M. H. A., \& Butar Butar, S. (2020). Pengaruh tata kelola perusahaan, reputasi KAP, karakteristik perusahaan dan opini audit terhadap audit delay. Jurnal Akuntansi Bisnis, 18(1), 1-19. https://doi.org/10.24167/jab.v18i1.2698

Debbianita, Hidayat, V. S., \& Ivana. (2018). Pengaruh profitabilitas, solvabilitas, dan aktivitas persediaan terhadap audit delay pada perusahaan retail yang terdaftar di Bursa Efek Indonesia periode 2014-2015. Jurnal Akuntansi Maranatha, 9(2),

158-169. https://doi.org/10.28932/jam.v9i2.484

Felicia, W., \& Pesudo, D. A. A. (2019). Mengapa perusahaan terlambat menerbitkan laporan keuangan? Perspektif Akuntansi, 2(1), 71-88. https://doi.org/10.24246/persi.v2i1.p71-88

Firmansyah, R. Y., Sudarma, M., \& Widia, Y. P. (2016). Faktor internal dan eksternal yang berpengaruh terhadap kebijakan hutang dan nilai perusahaan (Studi empiris pada perusahaan BUMN non bank yang go-public di Bursa Efek Indonesia). Balance: Economic, Business, Management and Accounting Journal, 13(1), 25-43. http://journal.umsurabava.ac.id/index.php/balance/article/view/ $\underline{1565}$

Ghozali, I. (2016). Aplikasi analisis multivariete dengan program IBM SPSS 23, Edisi 8. Semarang: Badan Penerbit Universitas Diponegoro.

Ghozali, I. (2019). Aplikasi analisis multivariate dengan program IBM SPSS 25, Edisi 9. Semarang: Badan Penerbit Universitas Diponegoro.

Haifa, R. (2017). Pengaruh laba rugi, jenis industri, leverage, solvabilitas, profitabilitas terhadap audit delay (Studi pada perusahaan keuangan dan manufaktur yang terdaftar di Bursa Efek Indonesia tahun 2015). Skripsi. Universitas Muhammadivah Surakarta http://eprints.ums.ac.id/57196/

Hakim, L., \& Sagiyanti, P. (2018). Pengaruh ukuran perusahaan, jenis industri, komite audit, dan ukuran KAP terhadap audit delay. Jurnal Doktor Manajemen, $\quad I(02), \quad 58-73$. https://publikasi.mercubuana.ac.id/index.php/i $\mathrm{dm} /$ article/view/4125

Halim, V. (2000). Faktor-faktor yang mempengaruhi audit delay: Studi empiris pada perusahaan-perusahaan di Bursa Efek Jakarta. Jurnal Bisnis dan Akuntansi, 2(1),

63-75. https://jurnaltsm.id/index.php/JBA/article/vie $\mathrm{w} / 379$

Hati, R. P., \& Sari, I. R. (2020). Faktor-faktor yang mempengaruhi audit report lag pada perusahaan perbankan yang terdaftar di Bursa Efek Indonesia (Tahun 2013-2017). Measurement: Jurnal Akuntansi, 14(1), https://doi.org/10.33373/mja.v14i1.2509

Kartika, A. (2011). Faktor-faktor yang mempengaruhi audit delay pada perusahaan manufaktur yang terdaftar di BEI. Dinamika Keuangan dan Perbankan, 3(2), 152-171. https://www.unisbank.ac.id/ojs/index.php/fe1/ article/view/469
Kuncaratrah, H. J. (2019). Faktor-faktor penentu audit delay di Indonesia. Jurnal Akuntansi Universitas Jember, 17(1), 49-67. https://doi.org/10.19184/jaui.v17i1.9707

Kurniasih, T., \& Sari, M. M. R. (2013). Pengaruh return on assets, leverage, corporate governance, ukuran perusahaan dan kompensasi rugi fiskal pada tax avoidance. Buletin Studi Ekonomi, 18(1), 58-66. https://ojs.unud.ac.id/index.php/bse/article/vi $\underline{\mathrm{ew} / 6160}$

Kurniawan, A. I., \& Laksito, H. (2015). Analisis faktorfaktor yang mempengaruhi audit delay (Studi empiris pada perusahaan LQ 45 yang terdaftar di Bursa Efek Indonesia periode tahun 2010-2013). Diponegoro Journal of Accounting, 4(3), 1-13. https://ejournal3.undip.ac.id/index.php/accoun ting/article/view/16873

Lisa, O. (2015). Determinan audit delay dan timeliness. Jurnal Riset dan Aplikasi: Akuntansi dan Manajemen, $1(2)$, 100-110. https://doi.org/10.18382/jraam.v1i2.29

Miradhi, M. D., \& Juliarsa, G. (2016). Ukuran perusahaan sebagai pemoderasi pengaruh profitabilitas dan opini auditor pada audit delay. E-Jurnal Akuntansi, 16(1), 388-415. https://ocs.unud.ac.id/index.php/Akuntansi/art icle/view/17791

Mulyadi. (2014). Auditing (6th ed.). Jakarta: Salemba Empat.

Nugraha, N. B., \& Meiranto, W. (2015). Pengaruh corporate social responsibility, ukuran perusahaan, profitabilitas, leverage dan capital intensity terhadap agresivitas pajak (Studi empiris pada perusahaan non keuangan yang terdaftar di Bursa Efek Indonesia 2012-2013). Diponegoro Journal of Accounting, 4(4), 1-14. https://ejournal3.undip.ac.id/index.php/accoun ting/article/view/9672

Prameswari, A. S., \& Yustrianthe, R. H. (2017). Analisis faktor - faktor yang mempengaruhi audit delay pada perusahaan manufaktur yang terdaftar di Bursa Efek Indonesia. Jurnal Akuntansi Bisnis, 7(1), $\quad$ 50-67. https://doi.org/10.30813/jab.v7i1.776

Praptika, P. Y. H., \& Rasmini, N. K. (2016). Pengaruh audit tenure, pergantian auditor dan financial distress pada audit delay pada Perusahaan Consumer Goods. E-Jurnal Akuntansi, 15(3), 2052-2081.

https://ocs.unud.ac.id/index.php/Akuntansi/art icle/view/17786

Pratiwi, C. I. E., \& Wiratmaja, I. D. N. (2018). Pengaruh audit tenure dan kompleksitas operasi terhadap audit delay perusahaan pertambangan di BEI tahun 2013-2016. E-Jurnal Akuntansi, 24(3), 1964-1989.

https://doi.org/10.24843/eja.2018.v24.i03.p12

Primantara, I. M. D., \& Rasmini, N. K. (2015). Pengaruh jenis industri, spesialisasi industri auditor, dan opini auditor pada audit delay. E Jurnal Akuntansi Universitas Udayana, 13(3), 1001-1028. https://ocs.unud.ac.id/index.php/Akuntansi/art icle/view /14500

Purnami, N. K. Y., Kurniawan, P. S., \& Wahyuni, M. A. (2019). Pengaruh jenis industri, laba dan rugi operasi, dewan komisaris dan komite audit terhadap kecenderungan audit delay (Study empiris pada perusahaan LQ-45 Bursa Efek 
Indonesia tahun 2015-2017). Jurnal Ilmiah Mahasiswa Akuntansi Undiksha, 10(1), 49-60. https://ejournal.undiksha.ac.id/index.php/S1ak /article/view/20532

Putra, A. C., \& Wiratmaja, I. D. N. (2019). Pengaruh profitabilitas dan kompleksitas operasi pada audit delay dengan ukuran perusahaan sebagai variabel moderasi. E-Jurnal Akuntansi, 27(3), 2351-2375. https://doi.org/10.24843/eja.2019.v27.i03.p26

Rachman, D. A., \& Ardini, L. (2016). Analisis faktor-faktor yang mempengaruhi audit delay pada Perusahaan Telekomunikasi. Jurnal Ilmu dan Riset Akuntansi, 5(7), $1-14$. http://jurnalmahasiswa.stiesia.ac.id/index.php/ji $\mathrm{ra} /$ article/view/2012

Rahmawati, S. E., \& Suryono, B. (2015). Pengaruh faktor internal dan eksternal perusahaan terhadap audit delay dan timeliness. Diponegoro Journal of Accounting, 4(1), 167-176. http://jurnalmahasiswa.stiesia.ac.id/index.php/ji $\mathrm{ra} /$ article/view/3544

Rudyawan, A. P., \& Badera, I. D. N. (2009). Opini audit Going Concern: Kajian berdasarkan model prediksi kebangkrutan, pertumbuhan perusahaan, leverage, dan reputasi auditor. Jurnal Ilmiah Akuntansi dan Bisnis, 4(2), 1-17. https://ocs.unud.ac.id/index.php/jiab/article/vi ew/2612

Rustiarini, N. W., \& Sugiarti, N. W. M. (2013). Pengaruh karakteristik auditor, opini audit, audit tenure, pergantian auditor pada audit delay. Jurnal Ilmiah Akuntansi dan Humanika, 2(2), 657-675. https://ejournal.undiksha.ac.id/index.php/J」A/ article/view $/ 1676$

Saputri, O. D. (2012). Analisis faktor-faktor yang mempengaruhi audit delay. Skeripsi. Universitas Diponegoro. http://eprints.undip.ac.id/35333/

Sari, H. K., \& Priyadi, M. P. (2016). Faktor-faktor yang mempengaruhi audit delay pada perusahaan manufaktur tahun 2010-2014. Jurnal Ilmu dan Riset Akuntansi, 5(6), 1-17. http://jurnalmahasiswa.stiesia.ac.id/index.php/ji $\mathrm{ra} /$ article/view/1801

Scott, W. R. (2000). Financial accounting theory. United States: Prentice Hall.

Septariani, D. (2014). Pengaruh return on assets, debt to equity ratio dan ukuran kantor akuntan publik terhadap audit delay. Journal of Applied Business and Economic, 2(4), 331-344. https://iournal.lppmunindra.ac.id/index.php/IA $\mathrm{BE} /$ article/view/1526

Shulthoni, M. (2013). Determinan audit delay dan pengaruhnya terhadap reaksi investor. Jurnal Akuntansi Aktual, 2(1), 9-18. http://journal.um.ac.id/index.php/jaa/article/vi $\underline{\mathrm{ew} / 8315}$

Sulistiyanto, A., \& Yuniarto, A. S. (2012). Faktor-faktor yang berpengaruh terhadap audit delay pada perusahaan dagang di Bursa Efek Indonesia. Jurnal REKS A: Rekayasa Keuangan, Syariah dan Audit, 1(2), 95-110. https://doi.org/10.12928/i.reksa.v1i2.9

Sunaningsih, S. N., \& Rohman, A. (2014). Faktor-faktor yang berpengaruh terhadap audit delay (Studi empiris pada perusahaan sektor jasa yang terdaftar di Bursa Efek Indonesia periode tahun 2011 dan 2012). Diponegoro Journal of Accounting, 3(2),

$1-11$

https://ejournal3.undip.ac.id/index.php/accoun ting/article/view/6174

Suparsada, N. P. Y. D., \& Putri, I. A. D. (2017). Pengaruh profitabilitas, reputasi auditor, ukuran perusahaan, dan kepemilikan institusional terhadap audit delay. E-Jurnal Akuntansi, 18(1), 60-87.

https://ocs.unud.ac.id/index.php/Akuntansi/art icle/view/20800

Susianto, S. N. (2017). Pengaruh penerapan wajib IFRS, jenis industri, rugi, anak perusahaan, ukuran KAP, ukuran perusahaan, opini audit, dan ukuran komite audit terhadap Audit Report Lag (ARL) (Studi empiris pada perusahaan yang terdaftar di BEI periode tahun 2009-2013). Jurnal Akuntansi Bisnis, 15(1), 152-178. http://journal.unika.ac.id/index.php/jab/article $/$ view/1355

Sutjipto, V. F., Sugiarto, B., \& Biantara, D. (2020). Analisis pengaruh ukuran perusahaan, profitabilitas, solvabilitas, reputasi KAP dan opini auditor terhadap audit delay pada perusahaan yang terdaftar di Bursa Efek Indonesia tahun 20162018. Accounting Cycle Journal Universitas Agung Podomoro, 1(2), 85-99. http://journal.podomorouniversity.ac.id/index.p $\mathrm{hp} / \mathrm{ACJ} /$ article/view/117

Utami, W. (2006). Analisis determinan audit delay: Kajian empiris di Bursa Efek Jakarta. Buletin Penelitian, 9, 19-32.

https://www.academia.edu/1993502/Analisis Determinan Audit Delay Kajian_Empiris di_B ursa Efek Jakarta

Verawati, N. M. A., \& Wirakusuma, M. G. (2016). Pengaruh pergantian auditor, reputasi kap, opini audit, dan komite audit dalam audit delay. EJurnal Akuntansi, 17(2), 1083-1111. https://ocs.unud.ac.id/index.php/Akuntansi/art icle/view/19947

Widyastuti, M. T., \& Astika, I. B. P. (2017). Pengaruh ukuran perusahaan, kompleksitas operasi perusahaan dan jenis industri terhadap audit delay. E-Jurnal Akuntansi Universitas Udayana, 18(2), 1082-1111. https://ocs.unud.ac.id/index.php/Akuntansi/art icle/view/23399

Yohaniar, E., \& Asyik, N. F. (2017). Pengaruh profitabilitas, solvabilitas, size, komite audit, kompleksitas operasi dan opini auditor terhadap audit delay. Jurnal Imu dan Riset Akuntansi, 6(12), 1-19.

http://jurnalmahasiswa.stiesia.ac.id/index.php/ii ra/article/view/2014

Zebrivanti, D. E., \& Subardjo, A. (2016). Faktor-faktor yang berpengaruh terhadap audit delay pada perusahaan perbankan. Jurnal Ilmu dan Riset Akuntansi, 5(1), 1-18. http://jurnalmahasiswa.stiesia.ac.id/index.php/ii ra/article/view/1481 